Studia Anglica Posnaniensia 50/2-3, 2015

doi: 10.1515/stap-2015-0031

\title{
TWO ORAL HISTORIES OF THE TWO FIRST LADIES: JACQUELINE KENNEDY AND LADY BIRD JOHNSON
}

\author{
EWA MAJ \\ University of Wrockaw
}

\begin{abstract}
Two successful women, Jacqueline Kennedy and Lady Bird Johnson, influenced and were in turn influenced by the political careers of their husbands. An analysis of their oral histories, Jacqueline Kennedy: Historic Conversations on Life with John F. Kennedy (released in 2011) and Lady Bird Johnson: An Oral History (2012), demonstrates that John F. Kennedy and Lyndon Johnson became the first men of the American nation not only through their personal virtues, but also through the influence of their wives and who had a significant impact on their careers. Granted, both Jackie and Lady Bird extolled their husbands' merits, stressing that they were "only" their wives; however, both First Ladies played an essential diplomatic and political role, ensuring their husbands' physical and emotional well-being in private and public life. The article demonstrates how Jacqueline Kennedy and Lady Bird Johnson promoted the positive images of their husbands' terms in office via their oral histories and continued to do so after their deaths. Moreover, the article considers some important differences between the two histories. Jacqueline did not edit her previously authorized interviews, whereas Lady Bird made important changes to hers; furthermore, in direct contrast to Lady Bird, Jacqueline never wrote a memoir or autobiography, which makes her oral history the most valuable source on her views about her life and her husband's career.
\end{abstract}

Keywords: Oral history, Jacqueline Kennedy, Lady Bird Johnson, First Lady, Woman

\section{Introduction}

The lives of two successful women, Jacqueline Kennedy and Lady Bird Johnson, were inextricably bound with the political careers of their husbands. Indeed, John F. Kennedy and Lyndon Johnson became the first men of the American nation not only through their personal virtues or through the work of their political and Public Relations advisors, but also through the unfailing support of their wives. 
This support extended to improving the public images of their husbands through their utterances, speeches and conversations, which were later collected in two volumes known as their oral histories. Recorded and written down by historian Arthur Schlesinger Jr. (for Jackie Kennedy) and journalist Michelle Gillette (for Lady Bird), two tomes reveal the relationships Jacqueline Kennedy and Lady Bird Johnson had with each other and with their respective husbands. Knowing that they were being recorded, Jackie and Lady Bird formulated and implemented a plan of action directed towards bettering their husband's public images. Their oral histories reflect on their husbands' careers: it could be argued that they are not neutral recollections, but that they instead carefully focus on and capitalize on the best moments of the husbands. Consequently, I analyse the tomes Jacqueline Kennedy: Historic Conversations on Life with John F. Kennedy (released in 2011) and Lady Bird Johnson: An Oral History (2012) - to reveal the spin Jackie and Lady Bird put on their husbands' lives.

\section{Oral History Method}

Oral history is both a practice and a method of research. The act of recording a speech, it refers to the process of conducting and recording interviews in order to obtain information about the interviewees' past. Importantly, an oral history is the product of a particular interview and its context and the narrative account of past events - both as a research methodology and a result of the research process. In other words, it is an act of recording and a record that is being produced (Abrams 2010: 1-2). As such, it has certain limitations. During the meeting of the National Women's Studies Association in 1977, the participants realized that the traditional methodology of oral history did not advance the interests of women's oral history. It did not address valuable insights that were obtained from the women's liberation movement, such as the notion that the personal equals the political and women's experiences are inherently valuable and need to be recorded. Academics from a variety of disciplines were beginning to conceptualize an oral narrative as an avenue for understanding and documenting women's culture and history (Gluck and Patai 1991: 1). Indeed, oral history is a voluntary enterprise with no compulsion involved. Interviewees determine whether to participate, which questions they will answer, and how candidly or expansively they will do so. Interviewees can also control access to the final product (Gillette 2012: 6). For a narrator, the interview provides the opportunity to tell her own story in her own terms. For researchers, taped interviews preserve a living interchange for both present and future uses (Anderson and Jack 1991: 11). If a researcher is to appreciate and properly use the wealth of the collected material, he or she must construct a specific interpretative model able to take into account the narrative and textual dimensions, the social 
context, the symbolic representations brought into play, and, finally, the relations between these diverse elements (Chanfrault-Ducher 1991: 78).

The great power of oral history stems from the ease with which all kinds of voices can be recorded by all kinds of researchers. Ironically, the process of recording oral histories and thus making them accessible removes researchers from the original source, the speaker. But it is the words that must first of all be recorded, for these provide researchers with the basis for all scholarly endeavours and with the possibility of popular production (Gluck and Patai 1991: 221-222).

\section{First Ladies' Oral Histories and Their Goals}

Jacqueline Kennedy was interviewed three times after November 22, 1963, the day of the assassination of John F. Kennedy, thirty-fifth President of the United States of America, in Dallas, Texas. The first interview was conducted by Theodore Harold White in Hyannis Port in November, only a few days after John Kennedy's funeral. Jackie famously said that she and John listened to the record of the Broadway musical Camelot in the evening before they went to bed, and looking back, "that one brief shining moment" reminded her of his presidency. The second set of conversations was with William Manchester, who was writing a book called The Death of a President. During the sessions, Jackie divulged more than she intended about her husband's assassination; consequently, she sued the author and publisher and barred them from publishing her words in the book. As a result, the notes of the interviews have been sealed for 100 years, that is, until 2067. The third and the most important interview was her oral history (Kennedy C. 2011: 13).

Mrs Kennedy decided to share her memories and insights four months after her husband's death. The interview, as a part of the oral history project on the life and career of John F. Kennedy, was conducted by Arthur Schlesinger Jr., a former Harvard Professor and close friend of John F. Kennedy, as well as an advocate of the oral history method. Kennedy's daughter Caroline writes in the Foreword (2011: 11) that the interview was a gift from her mother's heart to the history of the United States of America. What is more, the recordings were left unpublished for 50 years and released only on the fiftieth anniversary of John F. Kennedy's Inauguration. That particular date seemed appropriate to Caroline because enough time had passed for Jacqueline's memories to be appreciated as a unique insight. Moreover, many living people still remember Kennedy's presidency and they find Jackie's observations illuminating.

Jacqueline Kennedy and Arthur Schlesinger Jr. met seven times in total. Schlesinger urged Jackie to speak as though addressing "a historian of the twentyfirst century". As he later recalled, "From time to time she would ask me to turn off the machine so that she could say what she wanted to say, and then ask, 
'Should I say that on the recorder?' (...) In general, what I would say was, 'Why don't you say it? ...You have control over transcript". She started to narrate with a trembling voice that grew stronger with time (Beschloss 2011:24).

In the Foreword, Caroline confirms (2011: 12) that after her father's death her mother resolved to do everything she could to make sure that the record of his administration was preserved. Jacqueline was certain that her husband's political decisions would stand the test of time and wanted future generations to know what an extraordinary man he was. Furthermore, at the end of 1963, Jacqueline was determined more than ever to win Jack a fair hearing from historians. She felt an enormous obligation to do whatever she could to ensure that her husband would not be forgotten (Beschloss 2011: 20-21).

In the meantime, Lady Bird's oral history is much different from Jacqueline's. As a woman who rarely did anything half-heartedly, Mrs Johnson intended her oral history to be as comprehensive as she could make it. Forty-seven interviews were conducted by American historian and journalist, Michael Gillette. The process of recording took eighteen years, with the transcripts released in 2012. Interviews began in August 1977, three years after the death of Lyndon Johnson, thirty-sixth President of the United States (Dallek 2004: 145-170). The meetings usually took place at weekends, at the Lyndon Johnson Ranch, where Lady Bird could focus on the topic for several hours without anyone interrupting her. Several sessions took place in Acapulco and Martha's Vineyard, where Mrs Johnson was vacationing with friends: she explained that her leisure would be more pleasurable if she was able to get some work done every day as well. The interviews proceeded chronologically (Gillette 2011: 5-6).

In the introduction to the book, Michael Gillette (2011: 6) highlights the fact that his oral history staff at the Lyndon Johnson Library compiled a detailed chronology for each year from appointment books, trip schedules, correspondence archives, and press coverage. Mrs Johnson personally reviewed both the chronology and the supporting materials before each session, making notes on items to be discussed. Gillette's questions typically introduced topics and sought for elaboration and clarification. To maximize the narrative's flow, the interviewer's questions were omitted from the book unless they provided the necessary context, with Lady Bird's reminiscences compressed to eliminate false starts, habitual crutch words, and repetitions.

It is not surprising that the clarity of Lady Bird's memories varied, with the interview sessions spanning almost two decades. The interviewee periodically refreshed her memory by looking through the volumes of photo albums that she kept at the Ranch. At times, she would be candid, expansive, and revealing; however, she could also be hesitant, vague, and uncertain. The quality of her recollections depended on whether she had actually participated in the events and how well she remembered them. For example, her recollections of Lyndon Johnson's 
legislative activities were almost always impressionistic, because she was not centrally involved in these matters. She did not always trust her memory, occasionally wishing that she recorded events immediately after they had taken place, when they were "red-hot", as she had done with her White House diary (Johnson 1970). In some instances, she relied more on the appointment books, letters, and chronologies in front of her rather than on her independent recollections. Some of her recollections are familiar stories that she had told multiple times; many others were episodes that she had not previously discussed in much detail, if at all (Gillette 2011: 6).

The impetus behind Lady Bird's oral history was her willingness to enhance the holdings of the Lyndon Johnson Library, but one must assume that she also intended to present her husband and his career in the most favourable lightindeed, the more controversial the topic discussed, the more emphatic her positive spin on events would become. Yet, she did at times criticize her husband, including the remark that he was sometimes his own worst enemy (Gillette 2011: 6).

\section{Presidents' Wives}

Jacqueline's interviews show, scene after scene, the history of the 1950s and 1960s. Her oral history becomes a refreshing personal account of John F. Kennedy's life as a senator, candidate, and President. Mrs Kennedy reveals the role she played in Kennedy's political life, diplomacy, and the unfolding world crisis (Kennedy [1964] 2011: 228-233 and 242-251). Jacqueline also entertains her readers and listeners by expressing her forthright and consistently original views about the changing cast of characters who surrounded her and her husband (Beschloss 2011:25). Significantly, even today many commentators presume that she remained largely indifferent to the politics of the day, as well-born and -bred young women of Jacqueline's generation were not encouraged to have an air of intellectualism about them (Bieluk 2011: 65; Tindall and Shi 2002: 1283). However, one also has to remember that it would not help her husband's cause for her to vent her more caustic opinions to anyone but their most trusted friends. Indeed, Jackie assures her interviewer that she shared her husband's political opinions, and her interviews with Schlesinger show that she was in fact very well informed about the political issues that concerned John F. Kennedy (Beschloss 2011: 25; Kennedy 2011: 264, 118-124, 139-152, 213, 221, 264, 257, 309, 319), with him confiding his political troubles in her during his presidency (2011: 78-96, 152, 203-214, 218). The couple grew especially close after his nomination for the presidency and during the Cuban Missile Crisis in 1962 (2011: 78-96, 152, 203-214, 218). Even though Mrs Kennedy emphasizes that she "[didn't] have political memories, because [she] shared a different part of life with him" (Kennedy 2011: 45), she still had an insider's knowledge and firm views about his very first steps 
in the world of politics, once defining his behaviour during his senator campaign as "reckless", but defending him on other occasions. When Max Freedman, a Manchester Guardian correspondent, asked her when her husband became so politically dedicated, it was obvious for Jacqueline (2011: 41-42, 45, 47, 93, 107$116,125-127)$ that her husband was always dedicated to politics, with her at his side during his vice-presidential and presidential campaign.

As a First Lady, Mrs Kennedy was not a feminist, at least not in the sense of the word as it is understood today. Betty Friedan's ground-breaking book, The Feminine Mystique, was published in 1963, but a fully-fledged women's movement was still almost a decade away. In her oral history, Mrs Kennedy suggests that women should find their sense of purpose through their husbands, and that the traditional style of marriage is "the best": "It seems to me that a woman always adapts, especially when she is getting married young and unformed. She becomes a woman, the way her husband wants to see her. When Jack did not want to talk about these things (politics) at home, I did not ask him" (Kennedy 2011: 87). Importantly, Jackie describes her first White House social secretary as "a sort of a feminist" and thus juxtaposes and contrasts her views to her own, observing that women should stay out of politics because they are too "emotional". She made it clear from the start that her main job was not to attend charity events or political banquets, but to raise her children well (Beschloss 2011: 26).

Despite her declarations, Mrs Kennedy's oral history reveals that her influence on Jack Kennedy's official relationships was not negligible. Jackie was obviously an asset to her husband with her command of French and Spanish, her knowledge of the history of Europe and its colonies, and her background in the arts (Beschloss 2011: 25). Schlesinger (2011: 167) highlights how proud Jack was of knowledge that he acquired from Mrs Kennedy, even though some researchers claim that Jack did not always appreciate her input (Bieluk 2011: 45). Without any doubt, Jacqueline transformed the role of the First Lady and became a golden standard against which other First Ladies would be measured. Since her engagement in the restoration of the White House, a bold venture she conceived and undertook out of her own initiative, every president's wife has felt compelled to focus on some important public project. A thirty-one-year-old housewife, Jackie wholeheartedly believed that her main job in the White House was to be a wife and a mother, but, as Lady Bird Johnson later recalled, Jacqueline had been an important player outside her nuclear family, with Lady Bird claiming that Jacqueline's contributions were not always properly recognized (Beschloss 2011: 29).

Despite her inherent modesty, Lady Bird Johnson's narrative documents show how central she was to Lyndon Johnson's political aspirations, as she gently nudged him forward despite his reluctance and despair, provided him with sound advice and unconditional love, while mollifying friends, members of the staff, and allies whom he had alienated. Their mutual dependence was profound. While 
he brought exhilaration, purpose, and inspiration to her life, she gave him love, stability, and thoughtful judgement he desperately needed (Gillette 2012: 4-5). He also sought her opinion on people and how to deal with them, even though their views would often be radically different, with her advocating leniency and understanding, and him stressing constancy and severity. In her own words, Lady Bird was "[v]ery proud [that] he did [acknowledge her views], [because] [she] wasn't the most assured person around, by any means, and [she] certainly was not very pushy. Sometimes [she] might have been helpful. Sometimes [she] might have made mistakes, but he was a bit inclined to go overboard on people". She also admits that she disagreed with him sometimes, "when he talked in times of anger", and was not sure if he even listened to her:

\footnotetext{
Because he didn't say anything in response. Sometimes I didn't even know if he'd heard [me]. Then maybe two or three days later, I'd hear him giving back the same thought like it was his own, and indeed, it was by process of osmosis. I'm sure I was useful. I am not a very creative, determined person and so my usefulness was in a milder vein. (Gillette 2012: 369).
}

At first, Lyndon Johnson became vice president to John Kennedy's president and replaced him after the 1963 assassination in Dallas, Texas (Gillion 2009: 87-168). However, Lady Bird opposed Lyndon's acceptance of the vice-presidential nomination in the 1960s:

\begin{abstract}
It was like trying to swallow a nettle: hurt, sticky, spiny. He didn't want the job, but he felt an enormous sense of obligation to the Democratic Party. It had given him, us, every honour it could: wearing the flag for a Democratic Party as a member of the House of Representatives and as a senator. It's hard for anybody now to understand how people felt then. There was a sense of party loyalty, of obligation, of belonging because you wanted to belong and of loyalty that [was] imposed on. (Gillette 2012: 313, 324).
\end{abstract}

In her oral history, Lady Bird admits that Lyndon Johnson was "a very free man", and she was not sure "how good number-two man he would be", but she underlines that "[a]t the same time, it was his life, his job, his career [and she] was not the fellow that was going to have to do the job, bear the burden. So [she] just really drew back from trying to persuade him. So that's about what [she] said to him. [She] wanted him to do what he must do" (Gillette 2012: 322). Simultaneously, as Jan Jarboe Russell (2014) convincingly stated in the thirteenth chapter of her biography of Lady Bird, historians have long debated why exactly Johnson withdrew from politics in 1968. One of the reasons could be that his wife refused to discuss political matters with him; however, Lady Bird's most impressive feat would indubitably be how she clandestinely orchestrated her husband's retreat from politics. In her diary, she jotted down the month and year in which he would 
announce his retirement - three years before he actually did it, and, by all accounts, before Johnson himself knew he would do it.

Mrs Johnson's political engagement and clout was also not insignificant: during Lyndon Johnson's campaigns, she played an increasingly active role and her zest for politics grew exponentially. Especially important was her work for ecological causes. As the First Lady, she assembled a professional staff in the East Wing of the White House and mobilized legions of influential, resourceful women and men to beautify and conserve the nation's environment. Wishing to lecture to the people of America in person, she travelled throughout the land to draw the audiences' attention to the beauty of the American environment and the growing threat to its sustainability. Through her husband's career, she entered "the society he thrust [her] into", a network of capable women and men who were rapidly changing America. Although Washington was a decidedly masculine society, women gathered in their own circles, convening enlightening seminars in a social atmosphere (Gillette 2012: 1-3). Lady Bird's oral history reveals in details the role she played in the Head Start program designed to alleviate poverty, and The Lady Bird Special, an epic four-day, 1, 700 mile campaign trip through the South by train, undertaken before the presidential election of 1964 (Gillette 2012: 355, 360-361). Prominently, Lady Bird accentuates in her history that the role of the First Lady changed over the years, along with the role of women in general:

\footnotetext{
Because each one of these is an individual who comes there, elected by one man only, and from her own personal background, and almost certainly without ever having planned, anticipated, prepared. At least, that was the case with me. So it's a role that is bound to change with each individual, but is bound to be affected by the general way that women behaved in the culture of the time that you're in. (Gillette 2012: 349).
}

\section{Behind the Scenes}

It may be considered as a fact that no oral history ever tells the entire story. Even though Jacqueline recounts some of private conversations she had with her husband and unveils parts of the domestic life of the First Couple, she confesses that Jack did not inform her about his every move and he often travelled alone after their wedding on September 12, 1953. However, one can infer that their intimacy and mutual personal attachment were remarkably strong, with her taking care of him when he suffered from excruciating pain in his spine (2011: 46, 48-49); at the same time, she was very proud of Jack's attitude and commended him for his resilience, stating that: 
took care of him, [she] put him to bed / but he was never vexed, he didn't like to talk about it and consciously took his mind off it, he invited friends to dinner or talked with someone, went to the movies, only not to sit down and suffer. (Kennedy 2011: 50-51).

She also emphasizes that she has never felt as a wife of an invalid and organized parties for Jack, "doing [her] best to invite cheerful, new people, with wonderful music, to pass those evenings in joyful atmosphere. He loved them" (Kennedy 2011: 52-56).

Crucially, Jacqueline never alluded to Jack's extramarital affairs, mostly focusing on the positive aspects of their marriage. However, she does briefly admit that, "[1]ife was fast with him, always mattered what he was doing that day / People say that at home he did not talk about politics with [her], but he actually did not talk about anything else. Life with him was like a rapid race. Only looking from perspective, [she was] able to assess accurately what had exactly happened" (Kennedy 2011: 39-40). Mrs Kennedy had to adjust her children's bedtime to the hectic lifestyle of their father, so that Caroline and John-John could spend evenings with him; unfortunately, there was little time left for Jackie and Jack for marital intimacy or conversations (2011: 76, 181-185). In addition, Jacqueline assures that the couple have never truly quarrelled; when a difference in opinions arose between them, she would "run to him with apologies and thr[o]w [her] arms around him, he [would laugh], and whole problem was gone. He never held grudges - that feature defined his personality" (Kennedy 2011: 259). She assures that her husband "loved everyone like a mother who has infinite love for her children / He loved [her] and my sister, who didn't have anything in common with politics, and was looking for joy and relaxation. He loved [them] all. As you know, [she was] not jealous" (Kennedy 2011: 53-54).

In her interview with Schlesinger, Jacqueline enumerates the ways in which she and Jack inspired each other (2011: 56, 70, 73-77, 125, 162, 167-169, 283). They shared knowledge about history and art. Jack suggested to Jackie which books she should read: she paid attention to his recommendations, but — as she admits-never found time to finish even a single tome from his list. On a personal note, she recounts how he took care of her while she was pregnant with John-John and sent her on holidays when she appeared tired. Nonetheless, theirs was not a perfect bliss. Kennedy at first took great interest in all ventures and projects of his wife, but in time he found himself more and more irritated with her more mundane undertakings. In turn, Mrs Kennedy does not hide that living in the White House was often trying and difficult for their family life. However, she claims that in the end she found a measure of happiness there: "Later on I thought that you never know what turns out to be the best for you / I think to myself that our marriage was like love renewals after short partings" (Kennedy 2011: 152 and 188). 
Similarly, Lady Bird in her oral history never mentions her husband's extramarital affairs, as she would have regarded doing so as both embarrassing and disloyal. Off tape, she confided to Michel Gillette that she tried to improve herself by observing and imitating other women whom Johnson found sexually appealing. In the interviews, she occasionally spoke of these women with admiration and even affection. Only once in their informal conversations she indulges in what Gillette regarded as criticism (2012: 5). Crucially, she appears to be entirely devoted to Lyndon:

\begin{abstract}
What I wanted mostly was to give him an island of peace, in which to operate and work and come home to and rest and be assured that he was in the midst of love and understanding and loyalty, and we could find there some fun and laughter, too. That's about it. I certainly was no great, vital dictator or even inspirer, because he was the creative one. But I think he valued my judgment, and I know we were better together than we were apart. (Gillette 2012: 371).
\end{abstract}

Characteristically, Lady Bird's views on Lyndon Johnson's character were quite complex, with her claiming that her husband was both generous and volatile, a person of contradictions:

\begin{abstract}
Marvelous. Contradictory. Great natural intelligence. Showman sometimes; hurtful sometimes; very often tender and giving. He was full of faults, too, and sometimes [made] misjudgments about people. He was an awfully good man to have around in a tight [situation]. He was one we always looked to when we didn't know the answers. He carried the heavy loads; I carried a whole lot of the exasperating dayto-day little loads. (Gillette 2012: 370).
\end{abstract}

Pointedly, Lady Bird acknowledges that she occasionally disagreed with Lyndon in private.

Certainly, and then gently and, I hope persuasively, say why. But I was not sure enough to say 'Please, I hope you'll do that. If you don't do that, so-and-so and soand-so is going to happen', because I didn't know it might not. The way ahead often looked murky to both of us, and I had the luxury of doing nothing, and he didn't have the luxury of doing nothing sometimes. (Gillette 2012: 370).

A telling feature of their mutual relationship is that Lady Bird is sure her husband "praised" her "too much", but at the same time he proficiently "used the weapon of sarcasm" against her, often hurting her feelings. Last, but not least, she admits that she wishes she listened to him more, dressed better and lived up to his expectations, confessing that "[she] did learn a lot from him on many important things" (Gillette 2012: 371). 


\section{Jacqueline Kennedy and Lady Bird Johnson}

Jackie and Lady Bird shared a special political relationship, with Lady Bird being the Second Lady to Jacqueline's First (Schulman 2007: 87, 99). Mrs Johnson in her oral history recalls her feelings when, after befriending Jacqueline as a young person, she suddenly became her second. Significantly, she stresses that the difference in status did not cause her any kind of discomfort: "For one thing, I do not have an overweening personal ambition / It's easy to see that she and I came from different worlds socially. Mine was country girl, loving being a country girl I At first, I had no idea what my role would be except to ease Mrs Kennedy's burdens" (Gillette 2012: 325, 349).

In reality, Lady Bird frequently stood in for Jacqueline at official functions (2012: 334). And what was Jackie's attitude to Lady Bird? In her interview conducted by Arthur Schlesinger Jr., Jacqueline hints at her dislike of Lyndon Johnson: in her view, Johnson was one of the gossipmongers who spread rumours about Jack's Addison's disease to weaken his chances for the presidential nomination, ceasing his smear campaign only after he was chosen for a Vice President. In a similar vein, Mrs Kennedy did not entirely approve of Lady Bird's behaviour:

\footnotetext{
Whenever Lyndon talked, Lady Bird pulled out her booklet - I have never seen a husband and a wife doing such things - she was like a well-trained hound. He was saying something unsophisticated - I don't know - 'Does your sister live in London?' - and Lady Bird wrote down Lee's name and next to it: 'London'. Everything. Each and every name, telephone number - it was...oh...different style of action." (2011: 114).
}

Schlesinger adds at this point that the Johnsons appeared to operate like a "hockey team", with Jacqueline only confirming his opinion (2011: 114).

\section{Conclusion}

Oral interviews are a particularly valuable tool for recording women's perspectives and giving them an audible voice, which has too often been silenced in maledominated environments. Indeed, anthropologists have observed how the expression of women's unique experience is often submerged, particularly in any situation where women's interests and experiences are not in accord with those of men. A woman's discussion of her life may combine two separate, often conflicting perspectives: one framed in concepts and values that reflect men's dominant position in the culture, and one framed in the more immediate realities of personal experiences of women. When the experiences of women do not fit male-dominant mental paradigms, alternative concepts and means of expression may not readily be available. Hence, women often inadvertently mute their own thoughts and 
feelings when they try to describe their own lives in the familiar and publicly acceptable terms of prevailing male-centred concepts and conventions. In order to hear the women's perspective accurately, we have to learn to listen to them in stereo, receiving both the dominant and muted channels clearly and tuning into them carefully to understand intricate links between them (Anderson and Jack 1991: 11).

Jackie's daughter Caroline indicates that even though her mother's utterances in the oral history primarily concern John Kennedy, we still can infer from her words what kind of person she was. Much is revealed in her statements, but even more through her tone of voice and perhaps most through things she chooses to omit. After reading the oral history of their grandmother, Caroline's (2011: 1517) children were puzzled by some of Arthur Schlesinger's questions, as he investigated personal rivalries and petty issues that have not stood the test of time; in fact, they wondered why he had not asked more questions about her as a person. While studying Jackie's oral history, it is important to notice the atmosphere of grief after her husband's death that pervades the text, and, more importantly, her main goal - to commemorate John F. Kennedy's presidency and present it in the best way possible. In that aspect, Jacqueline's oral history is unique, but Lady Bird Johnson's is exceptional as well. Both as a witness and participant in the unfolding events, Lady Bird vividly captures the pulse of life in Texas and Washington throughout four decades. At the heart of her narrative is the transformation of an extraordinary woman (Gillette 2012: 7).

But it is equally important to remember that oral histories are steeped in contexts that make them endlessly controversial and yet exciting and endlessly promising. As Alessandro Portelli, an oral historian, once wrote, he and his fellow researchers are always attempting to:

\footnotetext{
Convey the sense of fluidity, of unfinishedness, of an inexhaustible work in progress, which is inherent to the fascination and frustration of oral history - floating as it does in time between the present and ever-changing past, oscillating in the dialogue between the narrator and the interviewer and, melting and coalescing in the no-man's land from orality to writing and back. (2010: 1).
}

The controversial character of the oral history method, in combination with the controversial private lives of two First Ladies discussed in this article - their relations with their husbands, their emotional entanglements, hidden clouts and attempts at improving the images of the John F. Kennedy and Lyndon Johnson presidencies - explains why this particular research method provides us with some answers, but oftentimes also obscures certain problems. Only in conjunction with other sources researchers may form the most balanced and accurate picture of the marriages of the Kennedys and Johnsons: how the spouses influenced each other and were in turn influenced by the politics of the day. Indeed, despite 
all of the reservations enumerated above, Jackie and Lady Bird's memories are considered to be valuable sources, but remain what Portelli would call a "work in progress".

Furthermore, it should be stressed that while the Kennedys are to be seen as a next-door marriage, the Johnsons complemented each other's strengths and nullified their weaknesses. Jackie and Lady Bird recall details from their husbands' lives with palpable admiration and indicate they were "only" their wives. However, both First Ladies played important diplomatic and political roles, taking care of their husbands in private and in public. Jacqueline's daughter Caroline overtly stated that her mother would have changed a great deal of details in her oral history conversations after rereading them, but for some reason she did not do this, whereas Lady Bird made important changes to hers; furthermore, in direct contrast to Lady Bird, Jacqueline has never written an autobiography or memoirs, which makes her oral history the most valuable source on her views about her life and her husband's career. Significantly, Jacqueline Kennedy and Lady Bird Johnson promoted positive images of their husbands' terms in office via their oral histories. Their feminine voice was used via this method to once and for all counter all negative comments that have arisen and may arise in the future about their husbands' political careers. This sentiment was perhaps best expressed by Nina George, the author of the novel The Lavender Room, who made one of her male characters state that, "Women tell stories about the world. Men talk only about themselves" (George 2014: 173) [translation mine, EM].

\section{REFERENCES}

Abrams, Lynn. 2010. Oral history method. London \& New York: Routledge.

Anderson, Kathryn \& Dana C. Jack. 1991. Learning to Listen: Interview Techniques and Analyses. In Sherna Berger Gluck \& Daphne Patai (eds.), Women's words. The feminist practice of oral history, 11-27. New York \& London: Routledge.

Beschloss, Michael. 2011. Introduction. In Jacqueline Kennedy, Jacqueline Kennedy: historic conversations on life with John F. Kennedy, 19-32. New York: Hyperion.

Bieluk, Halina. 2011. Pierwsza dama i jej wizerunek [The First Lady and her image].Gdynia: Novae Res.

Chanfrault-Duchet, Marie-Francoise. 1991. Narrative structures, social models, and symbolic representation in Life Story. In Sherna Berger Gluck \& Daphne Patai (eds.), Women's words. The feminist practice of oral history, 77-93. New York \& London: Routledge.

Dallek, Robert. 2004. Lyndon B. Johnson. Portrait of a President. Oxford: Oxford University Press. George, Nina. 2014. Lawendowy Pokój [The Lavender Room]. Kraków: Wydawnictwo Otwarte. Gillette, Michael. 2012. Lady Bird Johnson: an oral history. Oxford: Oxford University Press. Gillion, Steven M. 2009. The Kennedy assassination. 24 hours after. New York: Basic Books. Johnson, Lady Bird. 1970. White House diary. London: Weidenfeld \& Nicolson. 
Kennedy, Caroline. 2011. Foreword. In Jacqueline Kennedy. Jacqueline Kennedy: historic conversations on life with John F. Kennedy, 13. New York: Hyperion.

Kennedy, Jacqueline. 2011. Jacqueline Kennedy: historic conversations on life with John F. Kennedy, 11-17. New York: Hyperion.

Russell, Jan Jarboe. 2014. Lady Bird: a biography of Mrs. Johnson. New York: Scribner.

Schulman, Bruce J. 2007. Lyndon B. Johnson and American liberalism. New York: Palgrave Macmillan.

Tindall George Brown \& David E. Shi. 2002. Historia Stanów Zjednoczonych. [America: A narrative history]. Poznań: Zysk i S-ka. 